Jurnal Santiaji Pendidikan, Volume 10, Nomor 2, Juli 2020 ISSN 2087-9016, e-ISSN 2685-4694

\title{
PELAKSANAAN MODEL PEMBELAJARAN PROBLEM BASED LEARNING DIBANTU METODE PRESENTASI UNTUK MENINGKATKAN PRESTASI BELAJAR IPA SISWA
}

\author{
I Nengah Suana \\ SMP Negeri 3 Banjarangkan \\ E-mail: suanainengah@gmail.com
}

\begin{abstract}
ABSTRAK
Penelitian ini dilaksanakan di SMP Negeri 3 Banjarangkan di kelas VII D yang kemampuan siswanya untuk mata pelajaran IPA cukup rendah. Tujuan penulisan Penelitian Tindakan Kelas ini adalah untuk mengetahui apakah model pembelajaran Problem Based Learning dengan metode presentasi dapat meningkatkan prestasi belajar siswa.Metode pengumpulan datanya adalah tes prestasi belajar. Metode analisis datanya adalah deskriptif baik untuk data kualitatif maupun untuk data kuantitatif. Hasil yang diperoleh dari penelitian ini adalah penerapan model pembelajaran Problem Based Learning dengan metode presentasidapat meningkatkan prestasi belajar siswa. Ini terbukti dari hasil yang diperoleh pada awalnya mencapai nilai rata-rata 63,45, pada siklus I mencapai nilai ratarata 70,93 dan pada siklus II mencapai nilai rata-rata 81,55.Kesimpulan yang diperoleh dari penelitian ini adalah penerapan model pembelajaran Problem Based Learning dengan metode presentasi dapat meningkatkan prestasi belajar IPA siswa.
\end{abstract}

Kata kunci: $\quad$ model pembelajaran problem based learning, metode presentasi, prestasi belajar

\section{ABSTRACT}

This research was carried out in SMP Negeri 3 Banjarangkan in class VII D where the ability of students for science subjects was quite low. The purpose of writing this Classroom Action Research is to determine whether the learning model Problem Based Learning with presentation methods can improve student achievement. The data collection method is a learning achievement test. The data analysis method is descriptive both for qualitative data and for quantitative data. The results obtained from this study are the application of the Problem Based Learning model with the presentation method can improve student achievement. This is evident from the results obtained initially reaching an average value of 63.45, in the first cycle reaching an average value of 70.93 and in the second cycle achieving an average value of 81.55. The conclusion obtained from this study is the application of the Problem Based Learning model with the presentation method can improve student achievement in science.

Keywords: problem based learning learning model, presentation method, learning achievement

\section{PENDAHULUAN}

Pemberlakuan pelajaran IPA diarahkan untuk proses meningkatkan pemahaman dan kemampuan siswa menganalisis sehingga dapat membantu siswa untuk memperoleh pemahaman yang lebih mendalam tentang alam sekitar.Proses pembelajaran IPA yang terjadi selama ini sering terjadi permasalahan. Permasalahan yang sering timbul selama ini di lapangan adalahcara mengajar guru yang sering menggunakan metode konvensional dan menjelaskan materi sesuai dengan yang ada di buku paket maupun LKS. Selain itu, dalam proses pembelajaran guru belum 
Jurnal Santiaji Pendidikan, Volume 10, Nomor 2, Juli 2020 ISSN 2087-9016, e-ISSN 2685-4694

menggunakan model pembelajaran yang mendukung dalam penjelasan materi, dan selama ini belum pernah diadakan praktikum untuk materi yang seharusnya ada praktikumnya.

(Suryosubroto, 2002) menyatakan bahwa seharusnya setiap guru secara mandiri mengembangkan kemampuannya agardalam proses pembelajaran yang mengembangkan keterampilan proses siswa dapat berhasil sehingga siswa dapat membangun konsep sendiri. Kondisi yang demikian menyebabkan siswa kurang terlatih untuk mengembangkan daya analisisnya dan mengaplikasikan konsepkonsep yang telah dipelajari dalam kehidupan nyata yang siswa lihat dan alami setiap hari, sehingga kemampuan berpikir kritis siswa kurang dapat berkembang dengan baik.

Hal yang sama juga terjadi di SMP Negeri 3 Banjarangkan.Berdasarkan hasil observasi yang peneliti lakukan, dapat diketahui bahwa pembelajaran IPA di kelas masih dilakukan secara konvensional. Metode yang digunakan masih dengan metode ceramah, yaitu siswa hanya mendengarkan pada saat guru sedang menjelaskan, proses pembelajaran hanya berpusat pada guru. Akibatnya prestasi belajar siswa hanya mencapai nilai rata-rata63,45.

Proses pembelajaran masih berpusat pada konsep yang tertulis di buku, sehingga siswa cenderung hanya menghafal konsep bukan memahami konsep.Keadaan tersebut juga didukung oleh anggapan siswa bahwa pelajaran IPA susah dipahami karena banyak kata-kata atau istilah asing, hal ini berakibat kurangnyaaktifnya siswa dalam proses pembelajaran. Pada saat guru menjelaskan materi pembelajaran mereka cenderung pasif dan hanya mendengarkan guru menjelaskan materi. Siswa belum mampu mengungkapkan suatu pendapat atau bertanya, alasannya karena malu, takut dan bahkan mereka bingung apa yang akan ditanyakan, karena tidak paham dengan materi yang dijelaskan oleh guru. Disamping itu, keterlibat siswa dalam proses pembelajaran, kurang mampu mengamati, menggolongkan, mengkomunikasikan dan menyimpulkan hasil belajar. Sehingga kemampuan naalisis siswa masih rendah.

Menghadapi kondisi yang sangat mengkhawatirkan, maka perlu adanya upaya perbaikan dalam proses pembelajaran agar dapat meningkatkan keterampilan proses dalam pembelajaran IPA. Salah satu alternatif yang digunakan yaitu dengan menggunakan model Pembelajaran Berbasis Masalah (Problem Based Learning). Model Pembelajaran Berbasis Masalah (PBL) merupakan suatu pendekatan dalam pembelajaran yang membantu siswa untuk menemukan masalah dari suatu peristiwa yang nyata, mengumpulkan informasi melalui strategi yang telah ditentukan sendiri untuk mengambil satu keputusan pemecahan masalahnya yang kemudian akan dipresentasikan dalam bentuk unjuk kerja.

Dengan penerapan model Pembelajaran Berbasis Masalah (PBL) diharapkan kemampuan analisis siswa dapat meningkat. Pembelajaran berbasis masalah tidak bisa terlepas dari metode pemecahan masalah, hal ini karena pembelajaran masalah berakar dari metode pemecahan masalah. Metode pemecahan masalah merupakan salah satu cara penyajian bahan pelajaran yang menjadikan masalah sebagai titik tolak pembahasan untuk dianalisis dan disintesis untuk menemukan jawaban. 
Jurnal Santiaji Pendidikan, Volume 10, Nomor 2, Juli 2020 ISSN 2087-9016, e-ISSN 2685-4694

Perumusan masalah mengandung deskripsi tentang kenyataan yang ada dan harapan yang diinginkan. Dalam penelitian ini rumusan masalah yang dapat disampaikan yaitu:Apakah pelaksanaan model pembelajaran Problem Based Learningdengan metode presentasi dapat meningkatkan prestasi belajar IPA siswa kelas VII D SMP Negeri 3 Banjarangkan semester I tahun pelajaran 2018/2019?Penelitian Tindakan Kelas ini dilakukan untuk mengatasi berbagai persoalan nyata guna memperbaiki atau meningkatkan kualitas pembelajaran di kelas. Apa yang menjadi tujuan penelitian ini disampaikan sebagai berikut:untuk mengetahui seberapa tinggi peningkatan prestasi belajar IPA siswa kelas VII D SMP Negeri 3 Banjarangkan semester I tahun pelajaran 2018/2019 setelah pelaksanaan model pembelajaran Problem Based Learningdengan metode presentasi.

Model pembelajaran merupakan kerangka konseptual yang melukiskan prosedur yang sistematis dalam mengorganisasi pengalaman belajar untuk mencapai tingkat belajar tertentu (Udin, 1997). Joyce, dkk. (2003) mengemukakan bahwa suatu model pembelajaran adalah suatu perencanaan atau pola yang digunakan sebagai pedoman pelaksanaan pembelajaran di kelas. Hamalik (2003) menjelaskan bahwa model pembelajaran merupakan suatu rencana atau pola yang digunakan untuk membentuk kurikulum, merancang bahan pengajaran dan membimbing pengajaran di kelas. Dari pendapat tersebut di atas dapat disimpulkan bahwa model pembelajaran merupakan kerangka konseptual dalam wujud suatu perencanaan pembelajaran yang melukiskan prosedur yang sistematis yang digunakan sebagai pedoman dalam pembelajaran di kelas.
Istilah model pembelajaran mempunyai empat ciri khusus yakni: 1) rasional teoretik yang logis yang disusun oleh para pencipta, 2) landasan pemikiran tentang apa dan bagaimana siswa belajar, 3) tingkah laku mengajar yang diperlukan agar model tersebut dapat berhasil, 4) lingkungan belajar yang diperlukan agar tujuan pembelajaran itu dapat tercapai (Wina Sanjaya, 2006: 128).

Sintaks suatu model pembelajaran menggambarkan keseluruhan urutan alur langkah yang pada umumnya diikuti oleh serangkaian kegiatan pembelajaran (Nana S., 1989: 43). Sintaks pembelajaran menunjukkan dengan jelas kegiatankegiatan apa yang perlu dilakukan oleh guru atau siswa dan tugas-tugas khusus yang dilakukan oleh siswa. Sintaks dari bermacam model pembelajaran mempunyai komponen yang sama seperti diawali dengan menarik perhatian siswa dan memotivasi siswa agar terlibat dalam proses pembelajaran. Demikian pula setiap model pembelajaran selalu mempunyai tahap menutup pelajaran. Namun demikian ada perbedaan seperti perbedaan pengelolaan lingkungan belajar, perbedaan peran siswa, perbedaan peran guru, perbedaan ruang fisik dan perbedaan sistem sosial kelas. Perbedaan-perbedaan tersebut harus dipahami oleh para guru dalam menerapkan model pembelajaran agar dapat dilaksanakan dengan baik.

Model pembelajaran problem based learning (pembelajaran berbasis masalah), awalnya dirancang untuk program graduate bidang kesehatan oleh Barrows, Howard (1994) yang kemudian diadaptasi dalam bidang pendidikan oleh (Gallagher, 1995) Problem based learning disetting dalam bentuk pembelajaran yang diawali dengan sebuah masalah dengan menggunakan instruktur sebagai pelatihan 
Jurnal Santiaji Pendidikan, Volume 10, Nomor 2, Juli 2020 ISSN 2087-9016, e-ISSN 2685-4694

metakognitif dan diakhiri dengan penyajian dan analisis kerja siswa.

Model pembelajaran problem based learning berlandaskan pada psikologi kognitif, sehingga fokus pengajaran tidak begitu banyak pada apa yang sedang dilakukan siswa, melainkan kepada apa yang sedang mereka pikirkan pada saat mereka melakukan kegiatan itu. Pada problem based learning peran guru lebih berperan sebagai pembimbing dan fasilitator sehingga siswa belajar berpikir dan memecahkan masalah mereka sendiri. Belajar berbasis masalah menemukan akar intelektualnya pada penelitian John Dewey (Ibrahim, 2000). Pedagogi Jhon Dewey menganjurkan guru untuk mendorong siswa terlibat dalam proyek atau tugas yang berorientasi masalah dan membentu mereka menyelidiki masalah-masalah tersebut. Pembelajaran yang berdayaguna atau berpusat pada masalah digerakkan oleh keinginan bawaan siswa untuk menyelidiki secara pribadi situasii yang bermakna merupakan hubungan problem based learning dengan psikologi Dewey. Selain Dewey, ahli psikologi Eropa Jean Piaget tokoh pengembang konsep konstruktivisme telah memberikan dukungannya. Pandangan konstruktivismekognitif yang didasari atas teori Piaget menyatakan bahwa siswa dalam segala usianya secara aktif terlibat dalam proses perolehan informasi dan membangun pengetahuannya sendiri (Ibrahim, 2000).

Langkah-langkah yang perlu diperhatikan dalam merancang program pengajaran yang berorientasi pada problem based learning sehingga proses pembelajaran benar-benar berpusat pada siswa (student centered) adalah sebagai berikut (Gallagher \& Stepien, 1995): 1) Fokuskan permasalahan (problem) sekitar pembelajaran konsep-konsep esensial yang strategis. Gunakan permasalahan dan konsep untuk membantu siswa melakukan investigasi substansi isi (content). 2) Berikan kesempatan kepada siswa untuk mengevaluasi gagasannya melalui eksperimen atau studi lapangan. Siswa akan menggali data-data yang diperlukan untuk memecahkan masalah yang dihadapinya. 3) Berikan kesempatan kepada siswa untuk mengelola data yang mereka miliki yang merupakan proses metakognisi. 4) Berikan kesempatan kepada siswa untuk mempresentasikan solusi-solusi yang mereka kemukakan. Penyajian dapat dilakukan dalam bentuk seminar atau publikasi atau dalam bentuk penyajian poster.

(Wina Sanjaya, 2006) menyatakan keunggulan problem based learning adalah: 1) Pemecahan masalah merupakan teknik yang cukup bagus untuk lebih memahami isi pelajaran. 2) Pemecahan masalah dapat menantang kemampuan siswa serta memberikan kepuasan untuk menemukan pengetahuan baru bagi siswa. 3) Pemecahan masalah dapat meningkatkan aktivitas pembelajaran siswa. 4) Pemecahan masalah dapat membantu siswa bagaimana mentransfer pengetahuan untuk memahami masalah dalam kehidupan nyata. 5) Pemecahan masalah dapat membantu siswa untuk mengembangkan pengetahuan barunya dan bertanggung jawab dalam pembelajaran yang mereka lakukan. Disamping juga dapat mendorong untuk melakukan siendiri baik terhadap hasil maupun proses belajarnya. 6) Melalui pemecahan masalah bisa diperlihatkan bahwa setiap mata pelajaran pada dasarnya merupakan cara berpikir dan sesuatu yang dimengerti oleh siswa bukan hanya sekedar belajar dari guru atau dari buku saja. 7) Pemecahan masalah dipandang lebih mengasikkan dan 
Jurnal Santiaji Pendidikan, Volume 10, Nomor 2, Juli 2020 ISSN 2087-9016, e-ISSN 2685-4694

disukai siswa. 8) Pemecahan masalah dapat mengembangkan kemampuan siswa untuk berpikir kritis dan mengembangkan kemampuan mereka untuk menyesuaikan pengetahuan baru. 9) Pemecahan masalah dapat memberikan kesempatan kepada siswa untuk mengaplikasikan pengetahuan yang telah mereka miliki dalam dunia nyata. 10) Pemecahan masalah dapat mengembangkan minat siswa untuk secara terus-menerus belajar sekalipun belajar pada pendidikan formal telah berakhir.

Sedangkan kelemahannya adalah: 1) Manakala siswa tidak memiliki minat atau tidak memiliki kepercayaan sehingga masalah yang dipelajari sulit dipecahkan maka siswa akan merasa enggan untuk mencoba. 2) Keberhasilan pembelajaran ini membutuhkan cukup banyak waktu. 3) Tanpa pemahaman mengapa mereka berusaha memecahkan masalah yang sedang dipelajari, maka siswa tidak akan belajar apa yang mereka ingin pelajari.

Presentasi sebagai suatu kegiatan komunikasi yang dilakukan oleh seseorang dengan cara menjelaskan, memaparkan dan menyampaikan suatu maksud tertentu kepada orang lain atau kelompok orang secara formal.

Presentasti merupakan kegiatan pengajyan suatu topik, pendapat atau informasi kepada orang lain. Berbeda dengan pidato yang lebih sering dibawakan dalam acara bisnis. Tujuan dari presentasi bermacam-macam, misalnya untuk membujuk, untuk memberi informasi (biasanya dibawakan oleh seorang pakar), atau untuk meyakinkan (biasanya dibawakan oleh seseorang yang ingin membantah pendapat tertentu). Keahlian berbicara di hadapan hadirin merupakan hal yang sangat penting bagi siapapun yang ingin maju. Banyak presiden, manajer, wiraniaga dan pengajar yang menjadi sukses dan terkenal lewat keahlian berpresentasi (http://id.wikipedia.org/wiki/presentasi). Pengertian metode presentasi adalah penyajian materi secara lisan oleh pembicara dengan menggunakan ide dan pemikiran yang terorganisasi. Presentasi biasa dilakukan di dalam kelas kecil maupun besar. Dalam metode ini peserta dikondisikan untuk menerima penjelasan dalam waktu tertentu. Presentasi adalah salah satu strategi pembelajaran yang terdapat penyaji yang menyampaikan materi di depan kepada audience menggunakan media tertentu. Media yang biasa digunakan antara lain LCD, Poster, Peta dan lain-lain.

Tujuan dari pelaksanaan presentasi seperti yang disampaikan Efiaty (2011) adalah untuk: 1) Menyampaikan informasi. 2) Meyakinkan pendengar. 3) Menghibur pendengar. 4) Memotivasi dan menginspirasi pendengar untuk melakukan tindakan. 5) Menyampaikan pesan. 6) Membuat suatu ide atau gagasan. 7) Menyentuh emosi pendengar. 8) Memperkenalkan diri.

Langkah-langkah presentasi adalah: 1) Presentasi pengemas awal: Menjelaskan tujuan pembelajaran; Menyajikan bahan pelajaran (identifikasi definisi-definisi, memberikan contoh-contoh, melukiskan konteks dari contoh tersebut, mengadakan pengulangan); Mendorong penyadaran siswa terhadap pengetahuan dan pengalaman yang relevan. 2) Presentasi tugas atau bahan belajar: Menyajikan bahan; Menciptakan perhatian siswa; Membuat pengorganisasian secara eksplisit; Menyusun bahan ajaran lebih logis dan eksplisit. 3) Memperkuat organisasi kognitif: Menggunakan prinsipprinsip integrasi bahan pelajaran; Mendorong siswa kritis terhadap bahan; 
Jurnal Santiaji Pendidikan, Volume 10, Nomor 2, Juli 2020 ISSN 2087-9016, e-ISSN 2685-4694

Mencari kejelasan; Mendorong aktivitas belajar siswa.

(Djamarah dan Zein., 1994) mendefinisi-kan prestasi belajar sebagai hasil yang diperoleh berupa kesan-kesan yang mengakibatkan perubahan dalam diri individu sebagai hasil dari aktivitas dalam belajar. Kalau perubahan tingkah laku adalah tujuan yang mau dicapai dari aktivitas belajar, maka perubahan tingkah laku itulah salah satu indikator yang dijadikan pedoman untuk mengetahui kemajuan individu dalam segala hal yang diperolehnya di sekolah. Dengan kata lain prestasi belajar merupakan kemampuankemampuan yang dimiliki oleh siswa sebagai akibat perbuatan belajar atau setelah menerima pengalaman belajar, yang dapat dikatagorikan menjadi tiga ranah, yakni ranah kognitif, afektif, dan psikomotor.

Dengan mengkaji hal tersebut di atas, maka faktor-faktor yang dapat mempengaruhi prestasi belajar menurut (Purwanto, 2000) antara lain: (1) faktor yang ada pada diri organisme itu sendiri yang dapat disebut faktor individual, seperti kematangan/pertumbuhan, kecerdasan, latihan, motivasi, dan faktor pribadi, (2) faktor yang ada diluar individu yang disebut faktor sosial., seperti faktor keluarga/keadaan rumah tangga, guru dan cara mengajamya, alat-alat yang dipergunakan dalam belajar-mengajar, lingkungan dan kesempatan yang tersedia dan motivasi sosial. Dalam penelitian ini faktor ke 2 yaitu faktor yang dari luar seperti guru dan cara mengajarnya yang akan menentukan prestasi belajar siswa. Guru dalam hal ini adalah kemampuan atau kompetensi guru, pendidikan dan lain-lain. Cara mengajarnya itu merupakan factor kebiasaan guru itu atau pembawaan guru itu dalam memberikan pelajaran.
Juga dikatakan oleh Slameto (2003: 54-70) bahwa faktor-faktor yang mempengaruhi belajar banyak jenisnya, tetapi dapat digolongkan menjadi dua golongan saja, yaitu faktor intern dan faktor ekstem. Faktor intern diklasifikasi menjadi tiga faktor yaitu: faktor jasmaniah, faktor psikologis dan faktor kelelahan. Faktor jasmaniah antara lain: kesehatan, cacat tubuh. Faktor psikologis antara lain: intelegensi, perhatian, minat, bakat, motif, kematangan, kesiapan. Faktor kelelahan antara lain: kelelahan jasmani dan rohani. Sedangkan faktor ekstern digolongkan menjadi tiga faktor yaitu: faktor keluarga, faktor sekolah, faktor masyarakat. Faktor keluarga antara lain: cara orang tua mendidik, relasi antara keluarga, suasana rumah tangga dan keadaan ekonomi keluarga. Faktor sekolah antara lain: metode mengajar, kurikulum, relasi guru dengan siswa, relasi siswa dengan siswa, disiplin sekolah, pelajaran dan waktu sekolah, standar pelajaran, keadaan gedung, metode belajar dan tugas rumah. Faktor masyarakat antara lain: kegiatan siswa dalam masyarakat, mass media, teman bergaul, bentuk kehidupan masyarakat. Peningkatan prestasi belajar yang penulis teliti dalam hal ini dipengaruhi oleh faktor eksternal yaitu metode mengajar guru.

Sardiman (1988: 25) menyatakan prestasi belajar sangat vital dalam dunia pendidikan, mengingat prestasi belajar itu dapat berperan sebagai hasil penilaian dan sebagai alat motivasi. Adapun peran sebagai hasil penilaian dan sebagai alat motivasi diuraikan seperti berikut.

Dalam pembahasan sebelumnya telah dibicarakan bahwa prestasi belajar adalah hasil penilaian pendidikan tentang kemajuan prestasi siswa setelah melakukan aktivitas belajar. Ini berarti 
Jurnal Santiaji Pendidikan, Volume 10, Nomor 2, Juli 2020 ISSN 2087-9016, e-ISSN 2685-4694

prestasi belajar tidak akan bisa diketahui tanpa dilakukan penilaian atas hasil aktivitas belajar siswa. Fungsi prestasi belajar bukan saja untuk mengetahui sejauhmana kemajuan siswa setelah menyelesaikan suatu aktivitas, tetapi yang lebih penting adalah sebagai alat untuk memotivasi setiap siswa agar lebih giat belajar, baik secara individu maupun kelompok. Dalam pembahasan ini akan dibicarakan mengenai prestasi belajar sebagai hasil penilaian dan pada pembahasan berikutnya akan dibicarakan pula prestasi belajar sebagai alat motivasi. Prestasi belajar sebagai hasil penilaian sudah dipahami. Namun demikian untuk mendapatkan pemahaman, perlu juga diketahui, bahwa penilaian adalah sebagai aktivitas dalam menentukan rendahnya prestasi belajar itu sendiri.

Abdullah (dalam Mamik Suratmi, 1994), mengatakan bahwa fungsi prestasi belajar adalah: (a) sebagai indikator dan kuantitas pengetahuan yang telah dimiliki oleh pelajar, (b) sebagai lambang pemenuhan keingintahuan, (c) informasi tentang prestasi belajar dapat menjadi perangsang untuk peningkatan ilmu pengetahuan dan (d) sebagai indikator daya serap dan kecerdasan murid.

Mohammad Surya (1979), mengatakan bahwa faktor-faktor yang mempengaruhi prestasi belajar dapat dilihat dari berbagai sudut pandang, antara lain dari sudut si pebelajar, proses belajar dan dapat pula dari sudut situasi belajar.

Bila kita coba lihat lebih dalam dari pendapat di atas, maka prestasi belajar dipengaruhi banyak faktor. Faktor-faktor dari si pebelajar sendiri atau faktor dalam diri siswa dan faktor luar. Faktor dalam diri siswa seperti IQ, motivasi, etos belajar, bakat, keuletan, dan lain-lain sangat berpengaruh pada prestasi belajar siswa.

Penjelasan Surya selanjutnya adalah: dari sudut si pembelajar (siswa), prestasi belajar seseorang dipengaruhi antara lain oleh kondisi kesehatan jasmani siswa, kecerdasan, bakat, minat, motivasi, penyesuaian diri dan kemampuan berinteraksi siswa. Sedangkan yang bersumber dari proses belajar, maka kemampuan guru dalam mengelola proses pembelajaran sangat menentukan prestasi belajar siswa. Guru yang menguasai materi pelajaran dengan baik, menggunakan metode dan media pembelajaran yang tepat, mampu mengelola kelas dengan baik dan memiliki kemampuan untuk menumbuhkembangkan motivasi belajar siswa untuk belajar, akan memberi pengaruh yang positif terhadap prestasi belajar siswa. Sedangkan situasi belajar siswa, meliputi situasi lingkungan keluarga, sekolah dan masyarakat sekitar.

Dari uraian di atas, dapat disimpulkan bahwa prestasi belajar adalah hasil yang dicapai siswa setelah melakukan kegiatan belajar yang berbentuk angka sebagai simbol dari ketuntasan mata pelajaranIPA. Prestasi belajar ini sangat dipengaruhi oleh faktor luar yaitu guru dan metode. Hal inilah yang menjadi titik perhatian peneliti di lapangan.

\section{METODE PENELITIAN}

Pelaksanaan Penelitian Tindakan Kelas biasanya dilakukan dimana guru melaksanakan tugas mengajar. Untuk penelitian ini dilakukan di SMP Negeri 3 Banjarangkan.Langkah-langkah yang dilakukan dalam Penelitian Tindakan Kelas ini mengikuti alur rancangan yang disajikan oleh (Barrows, 1996)yaitu:Denganmulai adanya suatu 
Jurnal Santiaji Pendidikan, Volume 10, Nomor 2, Juli 2020 ISSN 2087-9016, e-ISSN 2685-4694

permasalahan. Setelah diketahui ada masalah, dibuat perencanaan, kemudian dilaksanakan, diamati dan dilakukan refleksi. Setelah refleksi akan terlihat permasalahan yang tersisa yang merupakan masalah baru. Dengan adanya masalah baru maka dibuat perencanaan ulang, dilaksanakan, diamati dan dilakukan refleksi. Bila permasalahan belum bisa diatasi maka dilanjutkan dengan siklus berikutnya.

Subjek penelitian adalah tempat peneliti memperoleh keterangan atau data penelitian. Yang menjadi subjek penelitian ini adalah peserta didik pada kelas VII D SMP Negeri 3 Banjarangkan yang belajar pada semester I Tahun Pelajaran 2018/2019 yang berjumlah 29 orang siswa.Yang dijadikan objek peneliti ini adalah peningkatan prestasi belajar siswa kelas VII D SMP Negeri 3 Banjarangkan.Waktu dari pelaksanaan penelitian ini dari bulan Juli 2018 s/d Nopember 2018. Adapun teknik pengumpulan data yang digunakan dalam penelitian ini menggunakan tes. Tes ini dimaksudkan untuk mendapatkan data tentang prestasi belajar peserta didik setelah diberikan tindakan.Penelitian ini menggunakan statistik deskriptif untuk mengklasifikasikan data berdasarkan kelompoknya masing-masing dari yang semula belum teratur menjadi mudah diinterpretasikan maksudnya oleh orang yang membutuhkan informasi tentang keadaan variabel tersebut. Selain itu statistik deskriptif juga berfungsi menyajikan informasi sedemikian rupa, sehingga data yang dihasilkan dari penelitian dapat dimanfaatkan.

\section{HASIL PENELITIAN DAN PEMBAHASAN}

Pada awalnya hasil penelitian diperoleh nilai rata-rata sebesar 63,45 dimana ada 2 orang $(6,90 \%)$ memperoleh nilai di atas KKM, 8 orang $(27,59 \%)$ memperoleh nilai sama dengan KKM dan sisanya sebanyak 19 orang $(65,52 \%)$ belum tuntas karena memperoleh nilai di bawah KKM. Berikut disajikan hasil penelitian pada siklus I :

Tabel 1. Data Kelas Interval Siklus I

\begin{tabular}{|c|c|c|c|c|}
\hline $\begin{array}{l}\text { No } \\
\text { Urut }\end{array}$ & Interval & $\begin{array}{c}\text { Nilai } \\
\text { Tengah }\end{array}$ & $\begin{array}{c}\text { Frekuensi } \\
\text { Absolut }\end{array}$ & $\begin{array}{c}\text { Frekuensi } \\
\text { Relatif }\end{array}$ \\
\hline 1 & $62-66$ & 64,00 & 10 & 34,48 \\
\hline 2 & $67-71$ & 69,00 & 8 & 27,59 \\
\hline 3 & $72-76$ & 74,00 & 7 & 24,14 \\
\hline 4 & $77-81$ & 79,00 & 1 & 3,45 \\
\hline 5 & $82-86$ & 84,00 & 2 & 6,90 \\
\hline 6 & $87-91$ & 89,00 & 1 & 3,45 \\
\hline & Total & & 29 & 100 \\
\hline
\end{tabular}

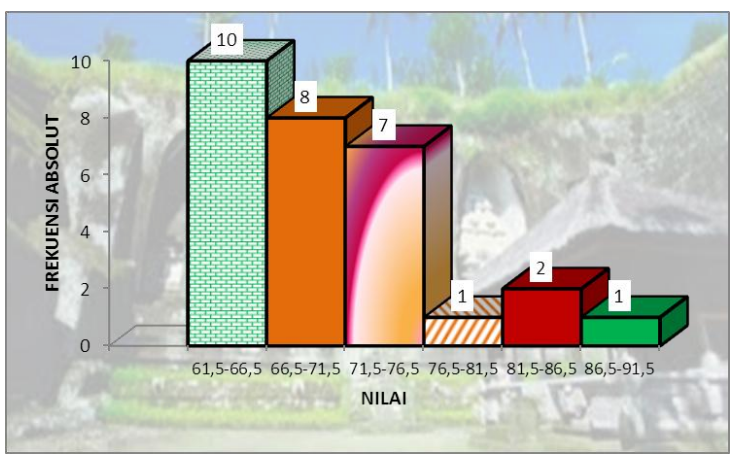

Gambar 1. Histogram Siklus I

Kelemahan-kelemahan yang ada dari pelaksanaan tindakan siklus I adalah: 1) Kebiasaan siswa yang sering bermainmain membuat siswa kurang termotivasi untuk giat belajar. 2) Siswa sering tidak mau belajar karena apabila ulangan siswa sudah mendapat jawaban/ contekan dari temannya. 3) Kemauan siswa untuk menyelesaikan tugas-tugas yang disuruh masih rendah. 4) Jarak rumah jauh dari sekolah dan alat transportasi tidak ada untuk mencapai sekolah tepat waktu karena berada di pedesaan. 5) Model bimbingan/metode ajar yang diterapkan guru kurang menarik, kurang bervariasi. 
Jurnal Santiaji Pendidikan, Volume 10, Nomor 2, Juli 2020 ISSN 2087-9016, e-ISSN 2685-4694

Sedangkan kelebihan yang ditemukan pada pelaksanaan tindakan siklus I adalah: 1) Peneliti mempunyai pengalaman lebih dalam melaksanakan model pembelajaran Problem Based Learning. 2) Siswa telah diupayakan belajar lewat penemuan.

Dari hasil yang diperoleh pada siklus I dilanjutkan dengan analisis yang diperoleh pada siklus II sebagai berikut:

Tabel 2. Data Kelas Interval Siklus II

\begin{tabular}{|c|c|c|c|c|}
\hline $\begin{array}{l}\text { No } \\
\text { Urut }\end{array}$ & Interval & $\begin{array}{c}\text { Nilai } \\
\text { Tengah }\end{array}$ & $\begin{array}{c}\text { Frekuensi } \\
\text { Absolut }\end{array}$ & $\begin{array}{c}\text { Frekuensi } \\
\text { Relatif }\end{array}$ \\
\hline 1 & $70-74$ & 72 & 2 & 6,90 \\
\hline 2 & $75-79$ & 77 & 4 & 13,79 \\
\hline 3 & $80-84$ & 82 & 13 & 44,83 \\
\hline 4 & $85-89$ & 87 & 4 & 13,79 \\
\hline 5 & $90-94$ & 92 & 5 & 17,24 \\
\hline 6 & $95-99$ & 97 & 1 & 3,45 \\
\hline & Total & & 29 & 100 \\
\hline
\end{tabular}

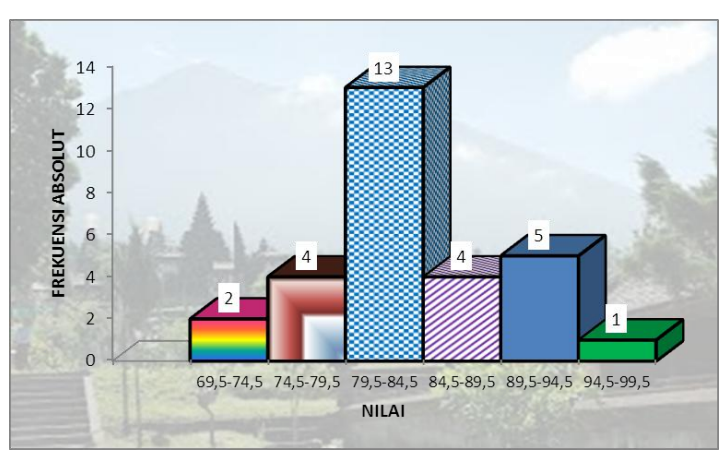

\section{Gambar 2. Histogram Siklus II}

Kekurangan-kekurangan yang ada dari pelaksanaan tindakan siklus II adalah: 1) Keadaan ekonomi orang tua yang lemah menyebabkan anak-anaknya harus ikut orang tua mencari nafkah dan membantu untuk mendapatkan penghasilan untuk keperluan sehari-hari. 2) Lingkungan peserta didik yang kurang mendukung untuk mereka aktif belajar.

Sedangkan kelebihan yang ditemukan pada pelaksanaan tindakan siklus II adalah: 1) Kegiatan dan kemauan peserta didik untuk giat bertanya sudah mampu dilakukan. 2) Kebiasaan siswa untuk memberi masukan kepada teman- temannya yang lain sudah dilakukan oleh semua peserta didik. 3) Persiapan peserta didik dalam berpresentasi di depan kelas sudah maksimal. 4) Pembelajaran sudah diupayakan agar peserta didik bisa mengalami langsung. 5) Contoh-contoh sudah cukup banyak. 6) Pembelajaran sudah diupayakan yang menuntut kemampuan dengan intelektual tinggi. 7) Penjelasan guru telah diupayakan yang bervariasi.

\section{Pembahasan}

Data awal yang diperoleh dengan rata-rata63,45 menunjukkan bahwa kemampuan siswa dalam mata pelajaran IPA masih sangat rendah mengingat kriteria ketuntasan belajar siswa untuk mata pelajaran ini di SMP Negeri 3 Banjarangkan adalah 70,00. Dengan nilai yang sangat rendah seperti itu maka peneliti mengupayakan untuk dapat meningkatkan prestasi belajar siswa menggunakan model pembelajaran Problem Based Learning dengan metode presentasi. Akhirnya dengan penerapan model pembelajaran Problem Based Learning dengan metode presentasi yang benar sesuai teori yang ada, peningkatan rata-rata prestasi belajar siswa pada siklus I dapat diupayakan dan mencapai ratarata70,93. Namun rata-rata tersebut belum maksimal karena hanya19 siswa yang dinyatakan tuntas sedangkan yang lainnya belum tuntas. Sedangkan prosentase ketuntasan belajar mereka baru mencapai65,52\%. Hal tersebut terjadi akibat penggunaan model pembelajaran Problem Based Learning dengan metode Presentasibelum maksimal dapat dilakukan disebabkan penerapan model/metode tersebut baru dicobakan sehingga guru masih belum mampu melaksanakannya sesua alur teori yang benar. 
Jurnal Santiaji Pendidikan, Volume 10, Nomor 2, Juli 2020 ISSN 2087-9016, e-ISSN 2685-4694

Pada siklus ke II perbaikan prestasi

belajar siswa diupayakan lebih maksimal dengan peneliti membuat perencanaan yang lebih baik, menggunakan alur dan teori dari model pembelajaran Problem Based Learning dengan metode Presentasi dengan benar dan lebih maksimal. Peneliti giat memotivasi siswa agar giat belajar, memberi arahan-arahan, menuntun mereka untuk mampu menguasai materi pelajaran pada mata pelajaran IPA lebih optimal. Akhirnya dengan semua upaya tersebut peneliti mampu meningkatkan prestasi belajar siswa pada siklus II menjadi ratarata81,55. Upaya-upaya yang maksimal tersebut menuntun pada suatu keberhasilan bahwa model pembelajaran Problem Based Learning dengan metode Presentasi mampu meningkatkan prestasi belajar IPA siswa kelas VII D SMP Negeri 3 Banjarangkan semester I tahun pelajaran 2018/2019.

\section{SIMPULAN DAN SARAN}

Pelaksanaan kegiatan awal dimana model pembelajaran yang digunakan tidak menentu, termasuk pula metode ajar yang digunakan hanya sekedar terlaksana membuat nilai siswa pada mata pelajaran IPA rendah dengan rata-rata 63,45 yang masih jauh dari kriteria ketuntasan minimal pada mata pelajaran ini yaitu 70,00 .

Setelah dilakukan perencanaan yang matang menggunakan model pembelajaran Problem Based Learning yang dilakukan dengan metode Presentasi, dilanjutkan dengan pelaksanaannya di lapangan yang benar sesuai dengan teori yang ada dan dibarengi dengan pemberian tes atau observasi secara objektif akhirnya terjadi peningkatan dari nilai rata-rata awal 63,45 menjadi 70,93 pada siklus I. Demikian juga terjadi peningkatan dari nilai rata-rata 70,93 pada siklus I meningkat menjadi 81,55 pada siklus II.

$$
\text { Seperti kebenaran tujuan }
$$

pelaksanan Penelitian Tindakan Kelas (PTK) yaitu untuk peningkatan proses pembelajaran, maka upaya-upaya yang maksimal telah dilakukan dengan sangat giat sehingga hasil yang diharapkan sesuai perolehan data telah mampu memberi jawaban terhadap rumusan masalah dan tujuan penelitian ini. Sehingga pelaksanaan model pembelajaran problem based learning dapat meningkatkan prestasi belajar IPA siswa kelas VII D SMP Negeri 3 Banjarangkan semester I tahun pelajaran 2018/2019.

Dari hasil analisis dan pembahasan hasil penelitian yang diperoleh dari uraian sebelumnya agar proses pembelajaran yang dilakukan di SMP Negeri 3 Banjarangkan lebih efektif dan lebih memberikan hasil yang optimal bagi siswa, maka disampaikan saran sebagai berikut: 1) Untuk melaksanakan pembinaan memerlukan persiapan yang cukup matang, sehinga disarankan agar guru mampu menentukan atau memilih topik yang bebar-benar bisa diterapkan dengan model pembelajaran Problem Based Learning sehingga diperoleh hasil yang optimal. 2) Agar mampu meningkatkan prestasi belajar, maka guru hendaknya lebih sering melatih siswa dengan kegiatan penemuan, walau dalam taraf yang sederhana, agar para siswa menjadi berminat terhadap kegiatan yang dilakukan sehingga keaktifan belajar akan meningkat. 3) Peneliti lain diharapkan melakukan penelitian lebih lanjut untuk meneliti bagian-bagian yang belum sempat diteliti.

\section{DAFTAR PUSTAKA}


Jurnal Santiaji Pendidikan, Volume 10, Nomor 2, Juli 2020 ISSN 2087-9016, e-ISSN 2685-4694

Arikunto, Suharsimi; Suhardjono; Supardi.

2006. Penelitian Tindakan Kelas.

Jakarta: PT Bumi Aksara.

Barrows, H. (1996). New Direction for Teaching and Learning "ProblemBased Learning in Medichine and Beyond; Abrief Overview.

Djamarah dan Zein. (1994). Dasar-Dasar Evaluasi Pendidikan. Bumi Aksara.

Gallagher, S. A. \& S. W. J. (1995). Implementing Problem Based Learning in Science Classroom.

Hamalik, O. (2003). Proses Belajar Mengajar. Jakarta Bumi Aksara.

Ibrahim, M. dan M. N. (2000). Pengajaran Berdasarkan Masalah. Surabaya Unesa University Press.

Mamik Suratmi. (1994). Beberapa Faktor Penyebab Kesulitan Belajar Matematika Siswa SMAN Wilayah Kota Singaraja. Tesis Program Pasca Sarjana IKIP, Malang.

Purwanto, N. (2000). Psikologi Pendidikan. Bandung: Rosdakarya.

Suryosubroto. (2002). Proses Belajar Mengajar di Sekolah. PT. Rineka Cipta. Jakarta.

Udin, S. . (1997). Teori Belajar dan Model-Model Pembelajaran. Depdikbud: Jakarta.

Wina Sanjaya. (2006). Strategi Pembelajaran Berorientasi Standar Proses Pendidika. Jakarta: Kencana Prenada Media. 